\title{
The passionate life of Simon Chan
}

\author{
Luca Comai*
}

This issue features a collaborative paper [1] between the Ian Korf and the Simon Chan laboratories describing the evolution of centromeric repeats in animal and plant genomes. Simon Chan passed away on August 222012 at the age of 38. Although the ongoing work of his coworkers will result in multiple additional papers carrying his name, this is the last paper he actively worked on.

Simon was born in Auckland, New Zealand. He graduated with a degree in biochemistry from the University of Auckland and earned a Ph.D. from UCSF, where he studied yeast telomeres under the guidance of Nobel laureate Elizabeth Blackburn. He did his postdoctoral research in the laboratory of Steve Jacobsen at UCLA working on RNA-directed DNA methylation and gene silencing. In 2006, Simon joined the faculty in the Department of Plant Biology at UC Davis. At that time, Simon took his passion for chromosomal biology and epigenetics into a new area: centromeric function and inheritance.

At UC Davis, Simon and his postdoctoral associate, Ravi Maruthlalacham, labored for three years studying the function of centromeric histone H3 (CENH3). Their approach was to complement a nullimorphic cenh3 mutant of Arabidopsis with genes encoding versions of CENH3 with varying degrees of alteration. They found that if a plant with an altered $\mathrm{CENH} 3$ was crossed to the wild type, many F1s were sterile. Chromosome mounts from these individuals revealed five chromosomes instead of ten, the expected diploid number. The hypothesis explaining these results had far-reaching implications: centromeres organized by a modified CENH3 were stable in crosses between similarly modified plants. However, when confronted in the zygote with centromeres determined by wild-type CENH3 the centromeres with the altered CENH3 lost out, causing the loss of the connected chromosomes. The resulting haploids could be easily converted to di-haploids (doubled haploids), enabling the establishment of pure inbreds in a single generation. This discovery, published in Nature in 2010 [2], has basic and

\footnotetext{
*Correspondence: Icomai@ucdavis.edu

Plant Biology and Genome Center, University of California, Davis, Davis, California 95616, USA
}

applied importance. For example, in a 2011 Science article [3], the Chan lab collaborated with Raphael Mercier and Imran Siddiqi to demonstrate the production of clonal plants through seeds in a process mimicking apomixis. This was done by crossing the haploid inducer line with a plant that bypassed meiotic recombination and reduction. In 2012, articles in PNAS [4] and Nature Genetics [5] illustrated, respectively, the use of CENH3-mediated genome elimination in the production of recombinant inbred lines and in molecular breeding. This research showed that it was possible to produce plants with a designated chromosomal composition using CENH3mediated breeding. Simon's scientific contribution was recognized in 2011 with the prestigious Howard Hughes Medical Institute Award- Gordon and Betty Moore Foundation Investigatorship.

Simon would have been well loved and respected even if his scientific career had not been as successful. His passionate, kind and friendly demeanor made him a popular teacher and colleague. He was also refreshingly informal. One of the pictures we treasure features Simon wearing a T-shirt and jeans, surrounded by others in business attire, explaining haploid induction to Bill Gates [6]. He was multi-talented: he played several instruments at nearly professional level, was broadly read, assembled his bicyles from used parts, cracked any puzzle, and had an encyclopic knowledge of both the trivial and the relevant. His friends remember with fondness his leadership in far-ranging culinary explorations, which he carefully recorded and annotated. His scientific promise and greater-than-life personality left a big vacuum in the lives of those who interacted with him, and beyond. We miss his scientific advice, his infectious smile, his stylish haircut, his colorful sneakers, his Hawaiian shirts, his tales and insights, his nodding off during seminars and his penetrating questions at the end. With no interest in material gains and personal wealth, he was passionate and intense about science, was dedicated to environmental sustainability and to making his inventions available to the developing world. He lived life to its fullest and made no compromise. Shortly before his death, he travelled to Africa to fulfill what he saw as his collaborative duties to local plant breeders and laboratories, which are aiming to apply Simon's findings to improve African staple crops. 
Simon had assembled an excellent team of junior scientists whose ongoing work is providing exciting insights into the fundamental questions raised by CENH3-mediated genomic elimination. In his last moments of consciousness during terminal hospitalization he would eagerly ask for updates. We hope that wherever he is, he is able to follow developments of his scientific discoveries. We, his colleagues and friends, are thankful that we could be associated with him even if the time was short.

\section{Acknowledgements}

I thank Ivalu Cacho for editing this manuscript.

Published: 30 January 2013

\section{References}

1. Melters DP, Bradnam KR, Young HA, Telis N, May MR, Ruby JG, Sebra R, Peluso P, Eid J, Rank D, Garcia JF, DeRisi JL, Smith T, Tobias C, Ross-Ibarra J, Korf I, Chan SW: Comparative analysis of tandem repeats from hundreds of species reveals unique insights into centromere evolution. Genome Biology 2013, 14:R10.
2. Ravi M, Chan SW: Haploid plants produced by centromere-mediated genome elimination. Nature 2010, 464:615-618.

3. Marimuthu MP, Jolivet S, Ravi M, Pereira L, Davda JN, Cromer L, Wang L, Nogué F, Chan SW, Siddiqi I, Mercier R: Synthetic clonal reproduction through seeds. Science 2011,331:876.

4. Seymour DK, Filiault DL, Henry IM, Monson-Miller J, Ravi M, Pang A, Comai L, Chan SW, Maloof JN: Rapid creation of Arabidopsis doubled haploid lines for quantitative trait locus mapping. Proc Natl Acad Sci U S A 2012, 109:4227-32.

5. Wijnker E, van Dun K, de Snoo CB, Lelivelt CL, Keurentjes JJ, Naharudin NS, Ravi M, Chan SW, de Jong H, Dirks R: Reverse breeding in Arabidopsis thaliana generates homozygous parental lines from a heterozygous plant. Nat Genet 2012,44:467-470.

6. UC Davis Department of Plant Biology website. [http://www-plb.ucdavis.edu/] doi:10.1186/gb-2013-14-1-103

Cite this article as: Comai L: The passionate life of Simon Chan. Genome Biology 2013, 14:103. 